\title{
Clivus Meningioma
}

National Cancer Institute

\section{Source}

National Cancer Institute. Clivus Meningioma. NCI Thesaurus. Code C5289.

A mening ioma that affects the clivus. 